\title{
The future of international business research on corporate globalization that never was...
}

\author{
Alain Verbeke ${ }^{1,2,3}$, \\ Régis Coeurderoy ${ }^{4,5}$ and \\ Tanja Matt ${ }^{6}$
}

\begin{abstract}
${ }^{1}$ Haskayne School of Business, University of Calgary, Calgary, AB T2N 1N4, Canada; ${ }^{2}$ Solvay Business School, Vrije Universiteit Brussel (VUB), Brussels, Belgium; ${ }^{3}$ Henley Business School, University of Reading, Reading, UK; ${ }^{4}$ ESCP Europe, Paris, France; ${ }^{5}$ Université Catholique de Louvain, Ottignies-Louvain-la-Neuve, Belgium; ${ }^{6}$ Technical University of Munich, Munich, Germany
\end{abstract}

Correspondence:

A Verbeke, Haskayne School of Business, University of Calgary, Calgary, AB T2N 1N4, Canada.

Tel: +1 403 220-8803;

Fax: +1 403 282-0095;

e-mail: alain.verbeke@haskayne.ucalgary.ca
Journal of International Business Studies (2018) 49, I I $01-1$ । I 2.

https://doi.org/10.1057/s41267-018-0192-2

\section{THE GLOBALIZATION THEME}

"Globalization" is one of the oldest and most recurrent themes in international business (IB) research. The concept refers to the growth and broadening scope of international economic exchange relationships of any one country with all other countries around the world, as measured by trade and foreign direct investment (FDI) flows, and other types of exchanges (capital, people, technology, ideas, effective institutional practices). Globalization has triggered extensive, ongoing measurement of several parameters at the macro-level, and has stimulated extensive dialogue on drivers, process dynamics, rates of change, and ultimate impacts. Business historians have shown that globalization tendencies, though deeply rooted in the history of various human civilizations, have unfolded through non-linear processes and with drivers and impacts that are still vigorously debated (Hopkins, 2002; O'Rourke \& Williamson, 2002; Jones, 2005).

In recent decades, globalization has sometimes been described as an irreversible process. The latest figures from the World Trade Organization suggest that the interdependency among countries is still rising, despite the 2008 great recession and much "noise" about the demise of globalization (WTO, 2017). However, globalization processes and their uneven impacts, especially in terms of wealth distribution, have increasingly come under attack. Globalization does generate feelings of discontent (Stiglitz, 2002, 2017), and a variety of "de-globalization" forces have gained at least some momentum around the world. Critics of globalization typically do the following. They engage in xenophobic attacks on foreign trade and investment partners' (whether countries or firms) comparative economic achievements, even within wealthy regions such as the European Union and North America. They voice heightened concerns about unequal distributive impacts, even though an increase of within-country inequality in the medium run, is arguably preferable to long term poverty. Moreover, increases in inequality in recent decades in developed countries have largely been the outcome of new technology adoption, the weakened power of organized labour and domestic tax policies, but are not the result of globalization. Finally, the critics irrationally equate globalization with both the demise of global public goods - such as the destruction of tropical rainforests or the extinction of particular 
animal species- and the rise of global public bads, such as the increase in greenhouse gas emissions and its visible environmental effects (Backman, Verbeke, \& Schulz, 2017).

The fact is that increased internationalization results in net-efficiency benefits. This is the great insight offered by much research in IB, commencing with the late John Dunning's brilliant treatise on the impacts of American investment in the British manufacturing industry (Dunning, 1958; second edition, 2006). Net efficiency-benefits reflect lower resource usage per unit of output, and the international diffusion of better industry practices, ranging from high quality accounting systems to proprietary technologies. Such types of outcomes have been clearly demonstrated in a large number of recent articles published in JIBS (see, inter alia, Berry, 2017; Brandl, Darendeli, \& Mudambi, 2018; Ellis, Moeller, Schlingemann, \& Stulz, 2017; Kano, 2018; Kim, Pevzner, \& Xin, 2018; Koning, Mertens, \& Roosenboom, 2018). The globalization of information flows has also dramatically increased the worldwide awareness of grand challenges such as climate change impacts and pollution of the oceans.

Unfortunately, in popular narratives, globalization has been associated with a new geography of discontent - mostly devoid of a sound factual basis. Such discontent is driven by perceptions of alleged, undesirable societal effects. Even individuals in geographic locations enjoying net efficiency-benefits from globalization appear to experience discontent. The picture of a high-profile, wealthy insurgent decrying human exploitation in the global textile industry, and advocating the purchase of locally produced clothing, while dressed in a suit of a global luxury brand, comes to mind.

The demise of many global public goods and the rise of public bads, can often be associated with human overpopulation. Here, globalization's role has primarily been to provide broader geographic access to life-saving medications such as vaccines, as well as medical services. ${ }^{1}$ It has also facilitated the easier distribution of essential goods to serve basic needs, and the diffusion of efficiency-enhancing institutional practices and management methods. Most negative spillovers of IB activities, apart from highly visible cases of market power abuse, have largely been the result of ineffective societal institutions, supposed to regulate economic activities but failing to do so. It is regrettable that the alleged (and mostly false) framing of "upward cascading" causal linkages between firm-level strategies and macro-level outcomes, especially in terms of undesirable spillovers from MNE activity, sometimes appears to override the facts on the net benefits of globalization. In addition, negative "downward cascading" linkages (such as domestic corruption imposed on foreign-owned firms), which are real, have seldom been recognized. In an article entitled "The Retreat of the Global Company" (Jan. 28, 2017), The Economist observed that the new de-globalization narratives at the macro-level can have negative spillovers at the firm-level. It predicted the rise of "a more fragmented and parochial kind of capitalism, and quite possibly a less efficient one ... the infatuation with global companies will come to be seen as a passing episode in business history."

But who has, or ever had "unreasoned passion" for the global firm? What exactly is this global firm, supposedly the outcome of a corporate globalization process, and then allegedly responsible for negative impacts at the macro-level? Corporate globalization could be viewed as the "end state" of internationalization at the micro-level, in terms of three elements:

(1) The firm commanding globally deployable and exploitable firm-specific advantages (FSAs), sometimes also referred to as "non-locationbound" FSAs, typically in the form of higherorder knowledge bundles, organizational practices and business models, and including managerial mindsets.

(2) The firm having both significant geographic breadth (i.e., a presence in many countries) and depth of international involvement (e.g., a significant percentage of overall assets and sales in various countries).

(3) The firm having a wide scope of value chain activities (with related organizational complexity) involved in its international operations, whether internally, or through the broader value chains with external actors, it participates in.

However, in spite of some observers speaking casually about a "flat world" (Friedman, 2005), whereby geography and other distance factors are becoming increasingly redundant, empirical research at the micro-level has shown that various form of regionalization, as well as localized clustering in narrow geographic space, is often more relevant than globalization (Rugman \& Verbeke, 2004; Verbeke \& Asmussen, 2016; Hillemann, 
Verbeke, \& Oh, 2018). For at least some key activities, such as core head office functions, home country origin matters as much now as it did two centuries ago, even in the world's largest firms (Coeurderoy \& Verbeke, 2016).

The main constraints on corporate globalization have been documented in a large and wide-ranging literature, and to the extent that these constraints are endogenous, they can usually be reduced to challenges of bounded rationality, bounded reliability, and the inability to create an organizational context conducive to value creation in its entirety, all of which become exacerbated as the firm broadens its geographic and product scope (Rugman \& Verbeke, 2001; Verbeke \& Kano, 2016; Narula \& Verbeke, 2015).

Verbeke and Forootan (2012) have shown that most research on alleged positive linkages between firm-level level multinationality (or level of global diversification) and performance is flawed, both conceptually and empirically. Few - if any - of the world's largest firms command the capabilities to achieve, and to sustain over longer periods of time, a balanced, global geographic distribution of their activities and sales. In their 2004 JIBS paper, Rugman and Verbeke identified only nine "global firms" in the Fortune Global 500, defined as firms with a balanced distribution of sales across the world (i.e., having less than $50 \%$ of sales in their home region, and at least $20 \%$ of in each of the two host regions of the triad of North America, Europe and Asia). These nine firms were (in declining order of sales): IBM, Sony, Royal Philips Electronics, Nokia, Intel, Canon, Coca Cola, Flextronics International and LVMH. Subsequent work by Oh and Rugman (2014) confirmed the quasi-absence of global firms with evenly distributed sales and assets across the world. Whether the definitions and metrics used were appropriate has been much debated, but the simple observation remains that most of even the world's largest firms are incapable of emulating the same level of home region success (as measured by sales and asset levels) throughout the world, because "distance" does continue to matter (Verbeke, 2013).

In addition to analysis of "global firms" that never were, there have been two other IB research streams on corporate globalization. The first stream is at the crossroads between international business and entrepreneurship. Scholars have coined the term "born globals" (Knight \& Cavusgil, 2004), referring to new ventures operating internationally from inception. However, companies with a broad geographic scope from inception remain the exception rather than the rule (Lopez, Kundu, \& Ciravegna, 2009; Verbeke \& Ciravegna, 2018). The second stream has addressed global value chains (GVCs), with few of these actually being "global" in terms of the indicators above (worldwide deployability of FSAs; significant geographic breadth and depth of the firm's reach; wide scope of value chain activities involved).

In Verbeke, Coeurderoy and Matt (2017), we have described in some more detail the IB literature's weaknesses when assessing the three above, expressions of corporate globalization. We have argued that the corporate globalization concept refers to a variety of supposedly empirical phenomena that never were, at least not as shown in the empirical literature. But our goal is not to lament poor conceptualizing, poor labeling, or poorly performed empirical work on corporate globalization. A major opportunity exists to develop a new corporate globalization research agenda, building upon better data. How should "global" in corporate globalization studies be defined in actionable terms, and how should its antecedents (contextual drivers) be established? How to assess corporate globalization empirically, in terms of content and consequences? How many large, truly global multinational enterprises (MNEs) exist? How many international new ventures qualify as born globals? How many international value chains are truly global?

At present, most past analyses of corporate globalization in IB research, simply appear to have "missed the target." There is an urgent need for better research, especially because such research would allow the IB research community to speak in a duly informed fashion on the content, context and consequences of corporate globalization. An informed IB research community could help debunk much of the disinformation and false narratives on the alleged negative spillover effects on society of internationally operating firms. At the more aggregate level, the IB research community could then also describe more compellingly the efficiency benefits brought by international economic activity, through foreign direct investment, exports or various types of external contracting across borders.

\section{A CRITICAL ASSESSMENT OF RESEARCH FINDINGS ON CORPORATE GLOBALIZATION}

\section{The Corporate Globalization Phenomenon}

The issue of corporate globalization has been debated mainly within the context of large MNEs 
and MNE strategy (e.g., Levitt, 1983; Kogut, 1985; Hamel \& Prahalad, 1985; Ohmae, 1985; Ghoshal, 1987; Rugman \& Verbeke, 2004; Rugman, Oh, \& Lim, 2012; Teece, 2014). There are three main perspectives on the subject matter. The first focuses on the firm's external context of homogenization, with this context conducive to either standardization or easier coordination of dispersed, heterogeneous activities (e.g., because of lower transportation costs; improved information and communications technology, absence of discriminatory treatment of foreign firms). In strategy terms, the firms' response must then be one focused on achieving scale and scope economies, or on economies of exploiting national differences, especially at the input side.

With the second perspective, the external context remains one of great (and sometimes increasing) heterogeneity. Global corporate success then results from appropriate resource recombination, with the firm's extant reservoir of non-location bound FSAs being bundled with locally accessed, complementary resources and newly developed, location-bound FSAs. Here, the firm focuses on achieving requisite levels of responsiveness to host environment circumstances (Verbeke, 2013).

With the third approach, the focus is on strategies similar to those in the first two approaches, but the firm operates within a more restricted geographic area, because optimal strategy implementation (e.g., a scale-based or resource-bundling initiative) is easier to achieve inside a more confined and homogeneous geographic zone (for analysis of the continued relevance of geographic distance, see Verbeke, Puck, \& van Tulder, 2017; Beugelsdijk, Ambos, \& Nell, 2018): Some form of regional strategy then typically substitutes for a more global approach. Or "globalization" can take the form of firms operating with distinct strategies for each region in which they have a presence (Ohmae, 1985; Verbeke \& Asmussen, 2016).

As noted above, the view on corporate globalization with established MNEs at its core, has been complemented with a research stream focused on born globals. Only in exceptional cases does a new firm's geographic reach actually fit the "global" label. Such cases include firms selling luxury goods, or operating in high-tech and IT niche markets, and requiring little adaptation or critical complementary resources at the downstream end. These firms may fit the born global mold (Hennart, 2014). In most cases, however, the "global" label in born globals, is more a reflection of strategic intent, rather than the realized outcome of a strategy.

Lastly, during the past two decades, an exciting new field of study has been developed on global value chains. Scholars from a variety of different backgrounds initiated this work: International economists (Baldwin, 2012); sociologists (Gereffi, Humphrey, \& Sturgeon, 2005); IB scholars (Kano, 2018; Mudambi \& Puck, 2016); and experts in the policy sphere (OECD, 2014). As noted by Mudambi and Puck (2016):

\begin{abstract}
When examining almost any GVC, we observe a constellation of organizational arrangements, ranging from contracts to alliances, partnerships and even spot market transactions. All GVC activities are essential to the creation of the final value proposition, but the geographical dispersion of these underlying activities is ignored when the entire value of final sales is ascribed to the location in which it occurs.
\end{abstract}

The "global" label in global value chains is thus useful as an acknowledgement of the organizational and stakeholder management complexity at hand, but paradoxically makes it more difficult to appraise what "global" actually means, in terms of the key, relevant parameters: The nature of the FSAs involved from the various partners, in terms of their non-location-boundedness; the geographic breadth and depth of the relevant value chain in its entirety; the scope of economic activities involved.

\section{Measurement Tools}

Corporate globalization is not only difficult to appraise conceptually, but its actual measurement is equally challenging. First, globalization has often been considered as the equivalent of a diversification process. Each new country entered is viewed as the equivalent of a new product line being added, and each entry draws upon the firm's resources reservoir. At the same time, commanding operations in several host countries can help reduce business risks: varying economic cycles and market trends can yield to more stable profit flows, at least to the extent that international markets indeed evolve independently from each other (Hitt, Li, \& $\mathrm{Xu}, 2016)$. In the same vein, the real options approach suggests that MNEs can disperse their operations across national boundaries in response to differences in environmental risks and opportunities, and then earn additional benefits from such geographic diversification (Chung, Lee, Beamish, \& Isobe, 2010). The most widely used measure of international diversification is an entropy index, 
along the lines of the index described in Jacquemin and Berry (1979) for business diversification. The index is defined as follows (Eq. 1), see, e.g., Hitt, Hoskisson and Kim (1997):

$$
\mathrm{ID}=\sum_{n=1}^{\infty}\left(P_{i} \times \ln \left(\frac{1}{P_{i}}\right)\right)
$$

In Eq. $1, P_{i}$ represents the sales attributed to region $i$ in the global market, and $\ln \left(1 / P_{i}\right)$ is the weight given to each region in the global market, or the natural logarithm of the inverse of its sales. The measure considers both the number of regions in the global economy in which a firm operates and the relative importance of each region in overall sales. Various authors have proposed adopting a more elaborate measure of international diversification (DT), integrating both geographic and business diversification (Kim, 1989). The purpose was to design an index measuring the geographic distribution of sales across relevant business segments, see Eq. 2:

$$
\mathrm{DT}=\sum_{a=1}^{A} \sum_{i \in a} P_{i a} \ln \left(\frac{1}{P_{i a}}\right)
$$

In Eq. 2, " $A$ " represents the number of geographic market areas in which a firm operates; $P_{i a}$ is the proportion of the size of the $i$ th business segment in the ath market area to a firm's total size of operations (Kim, 1989: 379).

Because of difficult-to-satisfy data requirements, the indices proposed by Kim (1989) and Kim, Hwang and Burgers (1993) have not been used much in subsequent, large-scale empirical work. The main practical reason is the difficulty to collect data on geographic coverage for each business segment. In contrast, the more simple entropy measure at the corporate level has been used much more frequently in IB studies (Hitt, Hoskisson, \& Kim, 1997). The entropy-based measure has limited value, however, if the goal is to capture the globalization phenomenon. When taking on extreme values, such an index is useful: A value close to one, points to a domestically oriented firm, while a value close to zero indicates strong dispersion across countries (as a supposed signal of globalization). But for the vast majority of companies, the entropy measure is not really informative. As one example, a Canadian MNE having equal sales volumes in the United States, Mexico and Canada will earn the same index score as a Canadian company with equal shares of sales in the United States, Japan and Germany. The entropy measure clearly does not take into account the "compounded distance" features of globalization (Rugman, Verbeke, \& Nguyen, 2011).

Second, many researchers have preferred to develop categorizations based on reaching "thresholds" (e.g., the presence or level of foreign sales; thresholds of sales percentages reached in specific regions), or based on simple counts (e.g., number of countries in which the firm operates). These measures represent superficial proxies for levels of multinationality. For instance, Morck and Yeung (1991) counted the number of foreign countries where an MNE has a subsidiary, and Wan and Hoskisson (2003) added "subsidiaries or cooperative ventures." McGahan and Victer (2010) proposed a count of the firm's number of foreign direct investments, as well as the number of countries in which it had engaged in FDI. In the realm of international new ventures, Zahra, Ireland and Hitt (2000) counted the number of countries entered by new companies. In index form, one can also find, e.g., the "count of host countries where a firm maintains offices in an observation year, divided by the sample maximum number of host countries across all observation years" (Powell, 2014).

When comparing the international diversification index with these types of "multinationality" indices, it could be argued that the latter do cover to some extent the increased organizational complexity associated with doing business in a higher number of countries, each being different in terms of culture, prevailing institutions, etc. It would also be correct to argue that being present in a larger number of countries does provide some indication of globalization, with the "maximum count" reflecting an economic presence in all countries in the world. The main weakness of this approach, unsurprisingly, is again, that this type of index can be meaningful at the extremes, but is more difficult to interpret when taking on intermediate scores (where most internationally operating firms are positioned). In the intermediate cases, it would be important to ask what shares of the firm's total sales, assets, and value chain activities are actually accounted for by each of these countries.

As regards the usage of thresholds rather than simple counts, one marker that has often been used is the distribution of sales across the main economic regions of the world, e.g., the Americas versus Europe, Mediterranean and Middle East, versus the Asia-Pacific, or some other supposedly relevant set of regions. Rugman and Verbeke (2004) 
proposed the following thresholds: Global firms were defined as having sales of at least $20 \%$ in each of the three regions of the broad triad of North America, Europe and Asia, but with less than 50\% in any one of these regions (especially the home region). Non-global MNEs would then include home-region oriented, host-region oriented or biregional MNEs. Debates have arisen about which regions should be used as the basis for the analysis; about the appropriate threshold levels to determine whether a firm is global (with some scholars arguing that overall GDP per region should be included as a correction factor, to determine which share of sales a global firm could reasonably expect from the various regions); about the need to assess other dimensions than revenues (for instance, assets); and about the relevant sets of companies to be included in corporate globalization studies (in Rugman and Verbeke's (2004) original work, the Fortune Global 500 companies were the basis of the analysis).

\section{Interrelated Empirical Caveats}

Scholarly articles have addressed corporate globalization for decades, but the previous section points to a number of interrelated weaknesses as to empirical assessment (see Verbeke \& Forootan, 2012; Verbeke, Coeurderoy, \& Matt, 2017). Three key interrelated challenges would appear critical here.

First, as noted above, scholars have often used rather crude proxies to measure corporate globalization. In some cases, even simple ratios have been used such as foreign sales/turnover, though these represent little more than an indicator of international activity (Errunza \& Senbet, 1984; Wiersema \& Bowen, 2008). In extreme instances, corporate globalization has been even assessed through usage of a dummy variable, indicating whether or not a company has any activity abroad, which is a disappointing corporate globalization measure (Denis, Denis, \& Yost, 2002; Chang, Kogut, \& Yang, 2016). It should also be noted that corporate globalization has been assessed almost exclusively on the basis of sales data. Only few published articles have included other parameters, such as asset or employee dispersion (Rugman \& Verbeke, 2008).

A second, related issue is the fact that authors most often aggregate data themselves or re-compute data, to assess corporate globalization. For instance, Hitt, Hoskisson and Kim (1997) write that, based on: "market sales data available in the
Compustat geographic segment tapes, we classified foreign markets into four relatively homogeneous global regions: Africa, Asia and Pacific, Europe, and the Americas. This action is based on the increasing importance of the regional economies (Ohmae, 1985, 1995)." Rugman and Verbeke (2004) adopted a similar approach. The above suggests that researchers typically face two methodological challenges: Firstly, rather than starting with understanding and aggregating firm-level data from the bottom-up, and gaining insight into the reasons for actual geographic dispersion, they start from the macro-level to establish regional geographic units. Secondly, they make arbitrary choices in the aggregation process, thereby introducing challenges for subsequent comparability and reproducibility.

A third empirical caveat concerns sample selection. On the one hand, authors who try to engage in a fine-grained analysis of corporate globalization have little choice than to eliminate many cases lacking the requisite information. As a result, Hitt, Hoskisson and Kim (1997) built their analysis on 295 US firms from the Compustat database; Qian, Li and Rugman (2013) used 167 Canadian firms; Hashai (2011) analyzed 144 Israeli high-technology firms; Rugman and Verbeke (2004) focused on only 320 firms. On the other hand, authors attempting to work with much larger samples, must operate with imperfect (and often inappropriate) proxies as noted above: Denis, Denis and Yost (2002) worked with a database of 44,288 firm-years, associated with 7520 firms (1984-1997); Chang, Kogut and Yang (2016) had a database of 12,640 firm-years, associated with 3002 firms (2005-2011).

\section{Implication: Corporate Globalization as a Missed Target in IB Research}

The various methodological and empirical weaknesses identified above, highlight that corporate globalization remains largely a "black box," in terms of what is actually known by IB scholars about its content, context and consequences, in spite of many academics writing about it. In their 2004 article, Rugman and Verbeke introduced their paper by stating that: "Globalization, in the sense of increased economic interdependence among nations, is a poorly understood phenomenon." Even though much progress may have been made in the realm of understanding globalization at the macro-level during the past 15 years, the statement remains largely valid for the corporate globalization phenomenon. 


\section{IMPROVING IB RESEARCH ON CORPORATE GLOBALIZATION}

\section{How to Improve Data Availability on Corporate Globalization}

Scholars engaged in corporate globalization research are mostly aware of the difficulties in conducting empirical work on this subject matter. There have been two main lines of debate on the issue, the first being related to designing tools measuring corporate globalization, and the second to actually assessing corporate globalization. The problem is that best practice methodologies, such as the one proposed by Kim (1989), though having been recognized as very promising, did not develop further and ultimately have experienced little adoption, because researchers were not able to obtain the requisite data to apply the instrument. Methodological issues can be debated and resolved within the IB research community, but data availability is largely an "external" challenge.

Most of the data used in corporate globalization studies come from external sources, and these provide only limited information on MNEs' international activities. In their article in the Journal of Finance, Denis, Denis and Yost (2002) clearly describe the problem. At that time, Compustat was the only database to provide information on MNEs' worldwide sales. As noted by the authors (Denis, Denis, \& Yost, 2002: 1958), Compustat provides some information on companies' geographical diversification, but with much less detail than for industrial segments. Compustat imposes limits on the number of segments - one for domestic sales (which means sales in the United States, because geographic information in the database is for US-based companies only), and a maximum of three extra segments. Consequently, Compustat operates the following process to provide information: It first re-allocates the segments reported by the companies themselves among seven geographical segments. Compustat then "regroups" these regions to obtain four global segments. This process implies that any single segment in the database might represent either one country or a very large geographic region with multiple countries.

Denis, Denis and Yost (2002) conclude:

Given these limitations, the number of global segments in which a firm operates has limited meaning and we do not report it as a measure of global diversification. In addition, because the database does not specify the individual countries that are included in each segment, we are unable to use the number of countries as a measure of global diversification (Denis et al., 2002: 1958).

Under these conditions, it is understandable why these authors decided to use a dummy variable for global diversification, if their goal was to build research upon a large dataset. But on the other hand, one can legitimately raise the question as to whether any insight at all on corporate globalization could reasonably be gained from such an approach.

Recently, Chang, Kogut and Yang (2016) replicated Denis et al.'s (2002) article. They complemented the Compustat data, with data from another - more recent - database, namely Orbis, which includes companies from around the world. But data availability appeared equally restrictive and the authors faced the same constraints as before. They therefore also addressed corporate globalization through usage of a dummy variable! In the first article, Denis et al. (2002) managed to build upon a sample of 44,288 firm-years associated with 7520 firms. In the second article, Chang et al. (2016) used a sample of 12,640 firm years associated with 3002 firms. Considering the very large size of these databases, one can only conclude that the authors felt compelled to eliminate a large number of companies, even though they used only a dummy variable to assess corporate globalization.

The producers of databases bear substantial responsibility for not making available data on corporate globalization that would actually be useful, as illustrated by Compustat's approach to include only three non-home geographic segments. But in fairness, a large part of the responsibility for poor data availability rests with the primary data providers, i.e., the MNEs and other internationally operating firms themselves. Coca-Cola, for example, provides relatively detailed data in its publicly available reporting on the geographic dispersion of its activities, including sales, capital investments, profits, etc. Similarly, Volkswagen also provides data on the dispersion of its sales and assets (including intangible assets) across regions. But when moving to Microsoft, the only distinction provided is between domestic and foreign sales. And the Chinese company Sinopec only makes available sales and assets in Mainland China versus the rest of the world.

What we can infer from these cases, representative of many other firms, is that information from the world's largest companies on their business activities abroad, is often missing. It is presented in 
idiosyncratic ways, and subject to firm-specific, discretionary choices as to intra-company data gathering and dissemination routines. The paradoxical outcome for the IB research community is that it has access only to non-standardized and often inadequate baseline information on what represents this community's main object of study, namely the internationally operating firm.

At present, IB researchers face the undesirable trade-off between using large samples with disappointingly poor corporate globalization information, and small samples with much better corporate globalization info. The main lesson to the drawn from this observation is that the IB community urgently needs access to better quality data, so as to improve its baseline knowledge on MNEs. The late Alan Rugman, one of the founders of the modern IB research field, famously stated that if every member of the Academy of International Business (AIB) studied just one internationally operating firm in great depth, the state of IB research would improve dramatically. The IB research community has accepted for too long to work with inadequate data. In an era when macro-level globalization is under fire, while at the same time the virtues of using "big data" in research are heralded, serious efforts should be made to collect and make available baseline corporate globalization data, as a foundation for better research on this important subject of academic inquiry. Absent such baseline information, IB researchers will find it difficult to participate meaningfully in the public debate on the "virtues versus sins" of internationally operating firms, and on these firms' broader societal impacts.

\section{What the IB Community Can Do on Its Own in the Short to Medium Term}

The above can elicit two types of reactions. On the one hand, IB researchers could simply accept the status quo and engage in "business as usual." Empirical work throughout the social sciences is fraught with challenges, including data limitations, and it could be argued that this is inherent to the work at hand. Even if IB empirical work is both unpolished and biased as a result, surely this state of affairs must be much better than not having this type of work performed at all. On the other hand, it could be argued that urgent improvements in data gathering and disclosure are required if IB research wants to take its rightful place next to the more established management sub-disciplines.
A first, short-term and easy to implement action, is to take corporate globalization seriously. This means that researchers should not claim they study globalization-related subject matter, if they do not even come close to properly defining and measuring it. In many cases, it would be much more accurate simply to write about internationalization. After getting the corporate globalization content right, the discussion must then focus more rigorously on both the context and consequences of corporate globalization. The immediate outcome of such "accuracy-focused" approach would undoubtedly be the recognition that knowledge on corporate globalization is much more limited that what is commonly assumed in the IB field and beyond. Here, the introduction of concepts such as born globals and global value chains may have enriched the debate in IB research on the various forms of international entry and operations, but it has also further muddled the waters on what corporate globalization actually implies. A renewed dialogue and consensus-building efforts in the IB research field on the meaning of corporate globalization, are in order.

A second, medium-term course of action would be to work more systematically on corporate globalization, by building upon easily accessible sources of information. Rugman and Verbeke (2004) launched a new research stream by studying the globalization (or rather the lack thereof) of companies included in the Global Fortune 500 ranking. Any choice of a particular set of firms included in a managerially oriented outlet, is open to valid criticism and debate. But selecting a baseline, freely available source of information on firms that truly matter in the world economy, at least in terms of their scale and visibility, and using a transparent and replicable approach to measuring globalization, can facilitate vigorous debate within the IB community. Such debate can then trigger a wave of publications, as well as a common understanding of the strengths and weaknesses of the underlying data. Parallel streams of research on other high quality datasets would be most welcome. One key to making progress in this area, is to have transparency and full disclosure of the datasets, so as to allow genuine, cumulative knowledge development. A debate along the lines suggested above, did materialize in the realm of regionalization (versus globalization), and included substantive discussion on the choice of appropriate thresholds to assess globalization (see, e.g., Osegowitsch \& Sammartino, 2008; Rugman \& Verbeke, 2008). 
Lessons drawn from research on corporate globalization for large MNEs should also be instructive when exploring born globals and global value chains. For these emerging topics, the "global" label often appears to be leveraged as a teaser, so as to make the research look more interesting. But this approach typically creates a large gap between what authors claim, and what has actually been observed. For these newer topics, it would be useful to: (1) correctly define concepts, e.g., defining "born global" as the extreme case of an international new venture that has internationalized quickly, deeply and broadly, and has a substantial presence all around the world; (2) develop a credible empirical research agenda, whereby what will actually be measured and assessed, is explained ex ante in great (step-by-step) detail.

\section{What the IB Research Community Must Do in the Longer Term: Pressures for Change}

The great paradox of corporate globalization research is that the scholars studying born globals and global value chains, most of which are not "global" by any reasonable standard, actually have a much better command of their data than the scholars studying large MNEs. The reason is that at least some information on the born globals studied is typically hand-collected, whereas the scholars studying global value chains also typically attach much importance to understanding their data.

The studies on the corporate globalization of large MNEs, inter alia in the realm of analyzing the performance impacts of global diversification, are typically the weakest. Scholars appear to lack an indepth command of their data, in the sense that they do not really know the firms in their samples, nor the management teams leading these firms, nor the business models deployed by these firms, etc. In the longer run, IB scholars cannot do serious work on corporate globalization, unless they gain access to good baseline data on the firms they are studying, and these firms become more than nameless black boxes about which little is known beyond some superficial internationalization characteristics and other quantitative information.

IB scholars would benefit greatly from a shift in policy practices by MNEs in terms of these firms gathering and subsequently disclosing better information on their international activities. Such a shift would equate to a "win-win-win" situation: Better information would support more reliable knowledge development on the content, context and consequences of MNE behaviour, which could in turn benefit strategy and public policy. The above logic is likely to remain "wishful thinking," however, if the dialogue on data were to involve only internationally operating firms and IB scholars. Individual firms will likely be reluctant to provide supplementary information if their competitors do not do the same, which reflects a typical prisoner's dilemma situation.

The most effective way to proceed would be to augment the information included in annual reporting as required by the relevant financial and accounting standards. At this time, geographic segment information is typically requested, but sharing such information is not really compulsory and disclosure largely depends on each company's approach to data gathering and sharing of information on its international activities (as illustrated by the firm-level examples above; see also, as an illustration, the United States FASB requisite disclosures about "segments of an enterprise").

Enhanced disclosures following more stringent international standards have already helped to improve information gathering and dissemination on the dispersion of MNE international activities. This is a commendable trajectory, but the next step must be to push for harmonizing across countries what information firms should file. A first step would be to use a generally accepted classification of regions for reporting the distribution of sales and assets. Many companies already do collect this baseline information for internal coordination and monitoring purposes. It would be a significant improvement if such data gathering, as well as data disclosure, were to become generalized and compulsory. This would be one small step undertaken by companies, but a giant leap forward for the IB research community.

\section{CONCLUSION}

Corporate globalization is a central theme in IB studies. Sound research in this realm requires accuracy in defining key concepts, proper measurement tools and access to reliable data. Much work is still required to craft consensus on the meaning of corporate globalization and on its appropriate measurement, as well as on what constitutes acceptable data to assess its content, context and consequences.

As stated, people who criticize macro-level globalization typically cannot defeat the argument about the net benefits of globalization (with the qualification that inequalities will also materialize, 
requiring policy measures to improve distributional justice). Critics who argue that global firms are a malign presence in host countries and thrive on alleged malevolent decision-making processes are, in fact, battling imaginary enemies. Like Don Quixote, they attack windmills, which they fear are ferocious giants. In reality, and adopting a micro-foundational perspective, corporate globalization processes are hampered by serious challenges of bounded rationality and bounded reliability, especially at the corporate head office level (Forsgren, 2017; Kano \& Verbeke, 2019). The outcome is that only few global firms exist.

There has been a false narrative propagating that multinational enterprises can just scan and scour the world for essential "strategic" complementary resources, which can then be used for value creating and capturing purposes. But novel resource combinations entail intense and challenging processes of melding the new resources involved, with extant capabilities. In most cases, the "complementary-resources acquisition" processes must be integrated into the functioning of "conventional" units, such as product divisions, in order to allow subsequent "scaling-up" and "replicability." The colocation of several linked activities is thereby often needed to create and capture value. This co-location requirement is amplified further in the digital economy space, when vertical and lateral complementary resources are needed "locally" to make an upstream technology exploitable and profitable. Here, national regimes thriving on the "forced sharing" of intellectual property by foreign companies in return for market access, may well represent the single most important threat to further corporate and macro-level globalization. Such forced sharing of proprietary knowledge also jeopardizes the related efficiency-benefits accruing to society at large. The amplification of strong upstream drivers of globalization, combined with opposing sociopolitical forces, should be a strong motivator for the IB research community to place knowledge creation (and translation) on corporate globalization at the forefront of its research agenda.

It is the mandate of the IB research community to conduct corporate globalization studies, building upon adequate firm-level data, and augmented with insight gained from senior management in the firms analysed. These studies will mostly demonstrate the vulnerability, rather than the ferociousness, of the few global firms, the few born globals and the few truly global value chains, presently in existence. The world needs more not less - globalization, to reap the efficiencies of novel resource combination processes. Successfully melding the extant FSA reservoirs of internationally operating firms with the complementary resources provided by actors in multiple host environments, requires a sequence of entrepreneurial decisions. Such decisions are necessarily guided by superior entrepreneurial judgment, but must also be associated with the disciplined implementation of firmspecific, managerial practices in support of geographic expansion. It has become abundantly clear that these managerial practices must artfully balance the goals of maximizing net efficiency-benefits and minimizing what could subsequently be construed as being negative, societal spillovers.

\section{ACKNOWLEDGEMENTS}

Earlier versions of this Commentary were presented at the Asia Academy of Management Conference, Fukuoka, Japan (2017); the University of International Business and Economics, Beijing, China (2017); and George Washington University, Washington DC, United States (2018).

\section{NOTES}

${ }^{1}$ Globalization, as a driver of improved population health, has thus been instrumental to creating a public good. This particular public good has nevertheless - through supporting human overpopulation - in turn been instrumental to the demise of many other public goods and the rise of several public bads. If the diffusion of modern medications and related medical practices is maintained, it is possible that population levels will actually fall in the longer run, inter alia - assuming a favorable institutional environment - because more women will obtain access to birth control products and more men will agree to women controlling their own reproductive capacity. 


\section{REFERENCES}

Backman, C. A., Verbeke, A., \& Schulz, R. A. 2017. The drivers of corporate climate change strategies and public policy: A new resource-based view perspective. Business and Society, 56(4): 545-575.

Baldwin, R. 2012. Global supply chains: Why they emerged, why they matter, and where they are going. CEPR Discussion Papers, No. 9103.

Berry, H. 2017. Managing valuable knowledge in weak IP protection countries. Journal of International Business Studies, 48(7): 787-807.

Beugelsdijk, S., Ambos, B., \& Nell, P. C. 2018. Conceptualizing and measuring distance in international business research: Recurring questions and best practice guidelines. Journal of International Business Studies. https://doi.org/10.1057/ s41267-018-0182-4.

Brandl, K., Darendeli, I., \& Mudambi, R. 2018. Foreign actors and intellectual property protection regulations in developing countries. Journal of International Business Studies. https://doi. org/10.1057/s41267-018-0172-6.

Chang, S., Kogut, B., \& Yang, J. S. 2016. Global diversification discount and its discontents: A bit of self-selection makes a world of difference. Strategic Management Journal, 37(11): 2254-2274.

Chung, C. C., Lee, S. H., Beamish, P. W., \& Isobe, T. 2010. Subsidiary expansion/contraction during times of economic crisis. Journal of International Business Studies, 41(3): 500-516.

Coeurderoy, R., \& Verbeke, A. 2016. The unbalanced geography of the world's largest MNEs: Institutional quality and head office distribution across countries. Global Strategy Journal, 6(2): 127-148.

Denis, D. J., Denis, D. K., \& Yost, K. 2002. Global diversification, industrial diversification, and firm value. The Journal of Finance, 57(5): 1951-1979.

Dunning, J. 2006; original version 1958. American investment in British manufacturing industry. New York: Routledge.

Ellis, J. A., Moeller, S. B., Schlingemann, F. P., \& Stulz, R. M. 2017. Portable country governance and cross-border acquisitions. Journal of International Business Studies, 48(2): 148-173.

Errunza, V. R., \& Senbet, L. W. 1984. International corporate diversification, market valuation, and size-adjusted evidence. The Journal of Finance, 39(3): 727-743.

Forsgren, M. 2017. Theories of the multinational firm: A multidimensional creature in the global economy. Cheltenham: Edward Elgar Publishing.

Friedman, T. L. 2005. The world is flat: A brief history of the twenty-first century. London: Macmillan.

Gereffi, G., Humphrey, J., \& Sturgeon, T. 2005. The governance of global value chains. Review of International Political Economy, 12(1): 78-104.

Ghoshal, S. 1987. Global strategy: An organizing framework. Strategic Management Journal, 8(5): 425-440.

Hamel, G., \& Prahalad, C. K. 1985. Do you really have a global strategy? Harvard Business Review, 63(4): 139-148.

Hashai, N. 2011. Sequencing the expansion of geographic scope and foreign operations by "born global" firms. Journal of International Business Studies, 42(8): 995-1015.

Hennart, J. F. 2014. The accidental internationalists: A theory of born globals. Entrepreneurship Theory and Practice, 38(1): 117-135

Hillemann, J., Verbeke, A., \& Oh, W. 2018. Regional integration, multinational enterprise strategy and country-level risk: The case of the EMU. British Journal of Management. https://doi. org/10.1111/1467-8551.12326.

Hitt, M. A., Hoskisson, R. E., \& Kim, H. 1997. International diversification: Effects on innovation and firm performance in product-diversified firms. Academy of Management Journal, 40(4): 767-798.

Hitt, M. A., Li, D., \& Xu, K. 2016. International strategy: From local to global and beyond. Journal of World Business, 51(1): 58-73.
Hopkins, A. G. (Ed.). 2002. Globalization in world history. New York: W. W. Norton.

Jacquemin, A. P., \& Berry, C. H. 1979. Entropy measure of diversification and corporate growth. The Journal of Industrial Economics, 27(4): 359-369.

Jones, G. 2005. Multinationals and global capitalism: From the nineteenth to the twenty first century. New York: Oxford University Press.

Kano, L. 2018. Global value chain governance: A relational perspective. Journal of International Business Studies, 49(6): 684-705.

Kano, L. \& Verbeke A. 2019. Theories of the multinational firm: A microfoundational perspective. Global Strategy Journal (forthcoming).

Kim, W. C. 1989. Developing a global diversification measure. Management Science, 35(3): 376-383.

Kim, W. C., Hwang, P., \& Burgers, W. P. 1993. Multinationals' diversification and the risk-return trade-off. Strategic Management Journal, 14(4): 275-286.

Kim, J. B., Pevzner, M., \& Xin, X. 2018. Foreign institutional ownership and auditor choice: Evidence from worldwide institutional ownership. Journal of International Business Studies. https://doi.org/10.1057/s41267-018-0160-x.

Knight, G. A., \& Cavusgil, S. T. 2004. Innovation, organizational capabilities, and the born-global firm. Journal of International Business Studies, 35(2): 124-141.

Kogut, B. 1985. Designing global strategies: Comparative and competitive value-added chains. Sloan Management Review, 26(4): 15.

Koning, M., Mertens, G., \& Roosenboom, P. 2018. Drivers of institutional change around the world: The case of IFRS. Journal of International Business Studies, 49(3): 249-271.

Levitt, T. 1983. The globalization of markets. Harvard Business Review, 61, 92-102.

Lopez, L. E., Kundu, S. K., \& Ciravegna, L. 2009. Born global or born regional? Evidence from an exploratory study in the Costa Rican software industry. Journal of International Business Studies, 40(7): 1228-1238.

McGahan, A. M., \& Victer, R. 2010. How much does home country matter to corporate profitability? Journal of International Business Studies, 41(1): 142-165.

Morck, R., \& Yeung, B. 1991. Why investors value multinationality. Journal of Business, 64(2): 165-187.

Mudambi, R., \& Puck, J. 2016. A global value chain analysis of the 'regional strategy' perspective. Journal of Management Studies, 53(6): 1076-1093.

Narula, R., \& Verbeke, A. 2015. Making internalization theory good for practice: The essence of Alan Rugman's contributions to international business. Journal of World Business, 50(4): $612-622$.

O'Rourke, K. H., \& Williamson, J. G. 2002. When did globalisation begin? European Review of Economic History, 6(1): 23-50.

OECD. 2014. Global value chains: Challenges, opportunities, and implications for policy. Report prepared for the G20 Trade Ministers Meeting. Sydney, Australia, 19 July 2014.

Oh, C. H., \& Rugman, A. M. 2014. The dynamics of regional and global multinationals, 1999-2008. Multinational Business Review, 22(2): 108-117.

Ohmae, K. 1985. Triad power: The coming shape of global competition. New York: The Free Press.

Ohmae, K. 1995. The end of the nation state: The rise of regional economies. New York: The Free Press.

Osegowitsch, T., \& Sammartino, A. 2008. Reassessing (home-) regionalisation. Journal of International Business Studies, 39(2): 184-196.

Powell, K. S. 2014. From M-P to MA-P: Multinationality alignment and performance. Journal of International Business Studies, 45(2): 211-226. 
Qian, G., Li, L., \& Rugman, A. M. 2013. Liability of country foreignness and liability of regional foreignness: Their effects on geographic diversification and firm performance. Journal of International Business Studies, 44(6): 635-647.

Rugman, A. M., Oh, C. H., \& Lim, D. S. 2012. The regional and global competitiveness of multinational firms. Journal of the Academy of Marketing Science, 40(2): 218-235.

Rugman, A. M., \& Verbeke, A. 2001. Subsidiary-specific advantages in multinational enterprises. Strategic Management Journal, 22(3): 237-250.

Rugman, A. M., \& Verbeke, A. 2004. A perspective on regional and global strategies of multinational enterprises. Journal of International Business Studies, 35(1): 3-18.

Rugman, A. M., \& Verbeke, A. 2008. A new perspective on the regional and global strategies of multinational services firms. Management International Review, 48(4): 397-411.

Rugman, A. M., Verbeke, A., \& Nguyen, Q. T. 2011. Fifty years of international business theory and beyond. Management International Review, 51(6): 755-786.

Stiglitz, J. E. 2002. Globalization and its discontents. New York: W.W. Norton.

Stiglitz, J. E. 2017. The overselling of globalization. Business Economics, 52(3): 129-137.

Teece, D. J. 2014. A dynamic capabilities-based entrepreneurial theory of the multinational enterprise. Journal of International Business Studies, 45(1): 8-37.

The Economist. 2017. The retreat of the global company. Jan. 28, 2017.

Verbeke, A. 2013. International business strategy. Cambridge: Cambridge University Press.

Verbeke, A., \& Asmussen, C. G. 2016. Global, local, or regional? The locus of MNE strategies. Journal of Management Studies, 53(6): 1051-1075.
Verbeke, A., \& Ciravegna, L. 2018. International entrepreneurship research versus international business research: A false dichotomy? Journal of International Business Studies, 49(4): 387-394.

Verbeke, A., Coeurderoy, R., \& Matt, T. 2017. The content, context and consequences of corporate globalization. Mimeo, Presentation at the 2017 Asia Academy of Management.

Verbeke, A., \& Forootan, M. Z. 2012. How good are multinationality-performance (M-P) empirical studies? Global Strategy Journal, 2(4): 332-344.

Verbeke, A., \& Kano, L. 2016. An internalization theory perspective on the global and regional strategies of multinational enterprises. Journal of World Business, 51(1): 83-92.

Verbeke, A., Puck, I., \& van Tulder, R. (Eds.). 2017b. Distance in international business: Concept, cost and value. Bingley: Emerald Publishing Limited.

Wan, W. P., \& Hoskisson, R. E. 2003. Home country environments, corporate diversification strategies, and firm performance. Academy of Management Journal, 46(1): 27-45.

Wiersema, M. F., \& Bowen, H. P. 2008. Corporate diversification: The impact of foreign competition, industry globalization, and product diversification. Strategic Management Journal, 29(2): 115-132.

WTO. 2017. World trade statistical review 2017. Geneva: World Trade Organization.

Zahra, S. A., Ireland, R. D., \& Hitt, M. A. 2000. International expansion by new venture firms: International diversity, mode of market entry, technological learning, and performance. Academy of Management Journal, 43(5): 925-950. 